\title{
Polyvinyl pyrrolidone (PVP) in cataract surgery
}

\author{
R. P. SARDA, J. M. MAKHIJA, AND R. G. SHARMA \\ Department of Ophthalmology, S.M.S. Medical College and Hospital, Jaipur, India
}

Early reformation of the anterior chamber after intraocular surgery is of paramount importance, its absence or delay leading to peripheral anterior synechiae and aphakic glaucoma (Troncoso, I933; Kronfeld and Grossman, I94I ; McLean, I941 ; Meyer and Sternberg, 1950). Selinger (1937) injected air after cataract operations to restore the normal curvature of the cornea. He concluded that air prevented blockage of the chamber angle by pressing on the iris hyaloid diaphragm and thus avoiding such postoperative complications as iris prolapse and secondary glaucoma. Barkan (195I) found that the intraocular pressure might rise after the injection of air, as air under pressure produced seclusion of the pupil. Lister (1957), in a case of irregular anterior chamber, withdrew air and introduced saline in its place with good results. Lytton (1963), while advocating the use of air, warned that the small air bubble might enter the posterior chamber and press the iris against the angle of the anterior chamber. Chacon Mendoza ( 1963 ) objected that air, being a foreign material, might lead to irritation and iris prolapse; he recommended the use of the patient's own aqueous, which could be removed before surgery and injected postoperatively.

King and McTigue (1964) used polyvinyl pyrrolidone (PVP) in the anterior chamber, after keratoplasty and glaucoma operations for the treatment of bullous keratopathy. In their own words: "Our use of PVP to replace aqueous after grafting and glaucoma was incidental. We had begun to use this method after Payran's trial, with the thought that it could be a treatment for bullous keratopathy".

PVP, a synthetic polymer of vinylpyrrolidone (Figure), is a glistening white flaky substance, soluble in water, giving a clear to yellow viscous solution with $\mathrm{pH} 4 \cdot 5$ to $7 \cdot 0$. It is freely soluble in most organic substances and also in saline. Aqueous solutions are stable and can be sterilized by autoclaving.

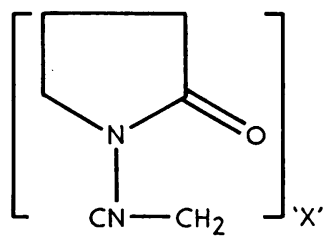

FIGURE Chemical formula of PVP

" $X$ " stands for the number of vinylpyrrolidone molecules which have entered to form PVP

The American brands $\mathrm{K}_{120}, \mathrm{~K} 60, \mathrm{~K}_{30}$, and $\mathrm{K}_{\mathrm{I}_{5}}$ have molecular weights of 360,000 ; I60,000; 40,000; and I0,000 respectively. Bayer's $\mathrm{K}_{25}$ and $\mathrm{K}_{1} 7$ have molecular weights of 30,000 and 12,600 .

PVP 4 per cent. has been used intravenously as a plasma substitute and PVP 25 per cent. as a slow-release vehicle for subcutaneous injections of penicillin, insulin, and other drugs. 


\section{Present Investigations}

\section{MATERIAL}

A total of 128 cataract cases was taken at random and divided into two groups: in 86 air was used to reform the anterior chamber and in 42 PVP. Table I shows the types of cataract treated in $\stackrel{?}{\frac{9}{9}}$ each group.

Table I Types of cataract

\begin{tabular}{|c|c|c|c|c|c|c|c|}
\hline Types of cataract & Immature & Mature & Senile & Congenital & Juvenile & Traumatic & Total \\
\hline Group I Air & 20 & 53 & I I & o & o & 2 & 86 \\
\hline Group II PVP & 9 & 15 & 13 & 3 & $\mathbf{I}$ & I & $4^{2}$ \\
\hline Total cases & 29 & 68 & 24 & 3 & $\mathbf{I}$ & 3 & 128 \\
\hline
\end{tabular}

\section{METHODS}

Solutions of PVP were prepared with physiological saline, $\mathrm{pH}$ adjusted to 7.3 by alkaline buffer solutions, and sterilized by autoclaving. $\mathrm{K}_{17}$ (25 per cent.), $\mathrm{K}_{25}$ (30 per cent.), and $\mathrm{K}_{25}$ (25을 per cent.) were used in different cases.

All cases were examined with the slit-lamp microscope before operation for damage to the corneal endothelium and iris.

Table II shows the method and type of lens extraction which were used in both groups.

Table II Methods of Extraction

\begin{tabular}{|c|c|c|c|c|c|c|}
\hline \multirow{3}{*}{ Operation } & \multicolumn{6}{|c|}{ Approach } \\
\hline & \multicolumn{2}{|c|}{ Intracapsular } & \multicolumn{2}{|c|}{ Extracapsular } & \multicolumn{2}{|c|}{ Total } \\
\hline & Air & $P V P$ & Air & $P V P$ & Air & $P V P$ \\
\hline Smith's & 6 & 4 & 35 & 18 & $4^{1}$ & 22 \\
\hline Forceps & 8 & 7 & 22 & II & 30 & 18 \\
\hline Erisophake & 2 & - & 8 & 2 & 0 & 2 \\
\hline Wire vectis & 3 & - & I & - & 4 & - \\
\hline Auto-expulsion & - & - & I & - & II & - \\
\hline Total cases & 19 & II & 67 & $3^{1}$ & 86 & $4^{2}$ \\
\hline
\end{tabular}

\section{COMPLICATIONS}

After the operation any complications, such as shallow anterior chamber, keratitis, hyphaema, gaping of the section, iris prolapse, and infection, were recorded.

On discharge a further slit-lamp examination was made to assess the extent or depth of keratitis, and pigment dispersal.

Only $5^{1}$ of the 86 in the group treated with air were so examined, but $4^{1}$ of the $4^{2}$ in the PVP group showed a smaller number of complications, which means that the incidence of complications in the controls would probably have been found to be even greater had they all been examined.

\section{Keratitis}

Table III shows the incidence in the two groups: 27.5 per cent. in the controls and 19.5 per cent. in those treated with PVP. Since the use of $\mathrm{K}_{1} 7$ (25 per cent.) and $\mathrm{K}_{25}$ (30 per cent.) was followed by keratitis and pigment dispersal in some of the early cases, $\mathrm{K}_{25}$ (25 per cent.) was used in all the later $\frac{\mathrm{O}}{\mathrm{O}}$ cases. Although PVP is a synthetic polymer of high molecular weight, it produced less keratitis
than air and no corneal oedema. 
Table III Incidence of keratitis

\begin{tabular}{|c|c|c|c|c|c|c|c|}
\hline \multirow{3}{*}{ Group } & \multirow{3}{*}{ Total cases } & \multirow{3}{*}{$\begin{array}{l}\text { No. examined } \\
\text { by slit lamp }\end{array}$} & \multicolumn{5}{|c|}{ Keratitis } \\
\hline & & & \multirow{2}{*}{ (I) } & \multirow{2}{*}{ (2) } & \multirow{2}{*}{ (3) } & \multicolumn{2}{|c|}{ Total } \\
\hline & & & & & & No. & Per cent. \\
\hline $\begin{array}{l}\text { I Air } \\
\text { II PVP }\end{array}$ & $\begin{array}{l}86 \\
42\end{array}$ & $\begin{array}{l}5^{I} \\
4^{I}\end{array}$ & $\begin{array}{r}10 \\
6\end{array}$ & $\begin{array}{l}3 \\
\text { I }\end{array}$ & $\begin{array}{l}\text { I } \\
\text { I }\end{array}$ & $\begin{array}{r}14 \\
8\end{array}$ & $\begin{array}{l}27 \cdot 5 \\
19 \cdot 5\end{array}$ \\
\hline Total & 128 & $9^{2}$ & 16 & 4 & 2 & 22 & - \\
\hline
\end{tabular}

(I) Superficial (2) Central (3) Severe

Shallow anterior chamber

The incidence was 4.7 per cent. in the PVP cases and 23.2 per cent. in the controls. King and McTigue (1964) observed 4 per cent. of shallow anterior chambers with PVP K6o in their cases.

Herniation of vitreous surface

This occurred more often in the controls, since the air, being lighter, does not hold the vitreous back.

Table IV shows the results of slit-lamp examination of the vitreous surface in 92 cases.

Table IV Abnormalities of vitreous face

\begin{tabular}{|c|c|c|c|c|c|}
\hline \multirow{2}{*}{ Group } & \multirow{2}{*}{ Total cases } & \multirow{2}{*}{$\begin{array}{l}\text { No. examined } \\
\text { by slit lamp }\end{array}$} & \multicolumn{3}{|c|}{ Vitreous surface } \\
\hline & & & Plane & Convex & Prolapsed \\
\hline I Air & 86 & $5^{I}$ & 2 & 16 & 8 \\
\hline II PVP & 42 & $4^{1}$ & 10 & o & o \\
\hline Total & I 28 & $9^{2}$ & 12 & 16 & 8 \\
\hline
\end{tabular}

There were 2 cases with vitreous loss in Group I

In the control group, the vitreous surface was found to be plane in two, convex in sixteen, and prolapsed into the anterior chamber in eight cases. With PVP ten cases showed a plane vitreous surface, but there was no case of herniation or vitreous prolapse.

Pigment dispersal

Table V shows that this occurred in 39 per cent. in the PVP group and in 49 per cent. of the controls.

Table V Pigment dispersal on vitreous surface

\begin{tabular}{|c|c|c|c|c|c|c|c|}
\hline \multirow{3}{*}{ Group } & \multirow{3}{*}{ No. of cases } & \multirow{3}{*}{$\begin{array}{l}\text { No. examined } \\
\text { by slit lamp }\end{array}$} & \multicolumn{5}{|c|}{ Pigment dispersal } \\
\hline & & & \multirow{2}{*}{$(\mathbf{I})$} & \multirow{2}{*}{ (2) } & \multirow{2}{*}{ (3) } & \multicolumn{2}{|c|}{ Total } \\
\hline & & & & & & No. & Per cent. \\
\hline I Air & 86 & $5^{1}$ & 21 & 4 & - & 25 & $49 \cdot 0$ \\
\hline II PVP & $4^{2}$ & 41 & II & 4 & $\mathbf{I}$ & 16 & $39^{\circ} 0$ \\
\hline Total & I 28 & 92 & 32 & 8 & $\mathbf{I}$ & $4^{I}$ & 一 \\
\hline
\end{tabular}

(1) Fine pigment on vitreous surface

(2) Thick pigment on vitreous surface or pigment keratic precipitates

(3) Thick pigment on vitreous surface plus pigment keratic precipitates 


\section{Hyphaema}

The incidence was higher (Io per cent.) in the PVP group than in the control group (4 per cent.) but two of these had sustained postoperative trauma and the other two had associated chroni? iritis, so that the PVP can hardly be blamed. King and McTigue (1964) reported hyphaema i蛋 Io per cent. of cases treated with PVP K6o.

\section{Discussion}

To prevent iris prolapse and secondary glaucoma, early reformation of the anterior chambe after intraocular surgery is essential.

PVP although a synthetic product, does not give rise to any foreign body reaction; and we observed fewer complications than with the use of air. It proved to be non-toxic non-infective, and non-allergic.

Being heavier than air, PVP exerts more pressure on the vitreous and prevents herniation and it is also less likely to cause the corneal dome to swell or to stretch the section and lead to iris prolapse.

Thanks are due to Bayer Products Bombay, Ltd., for supplying the PVP used in this work.

\section{References}

BARKAN, o. (1951) Amer. F. Ophthal., 34, 567

CHACON MENDOZA, A. (1963) Bull. Soc. franc. Ophtal., 76, 297

KING, J. H. (1967) Personal communication and mctigue, J. w. (1964) Sth. med. F., 57, i 369

Kronfeld, P. C., and Grossman, E. E. (194I) Trans. Amer. Acad. Ophthal. Otolaryng., 45, I84 LISTER, A. (1957) Brit. F. Ophthal., 41, I 15 Lytton, н. (1963) Amer. 7. Ophthal., 56, 647 mclean, J. м. (I94I) Trans. Amer. Acad. Ophthal. Otolaryng., 45, i 76 MEYER, S. J., and STERNBERG, P. (I950) Ibid., 54, 326 SELINGER, E. (1937) Amer. F. Ophthal., 20, 827 TRONCOso, M. U. (1933) In "XIV Concilium Ophthalmologicum 1933, Hispania", vol. I, pt

(Comunicaciones Libres), p. 25 